\title{
Effect of Grafting Height on Success and Subsequent Growth of Acid Lime (Citrus aurantifolia Swingle) Saplings
}

\author{
B. Chalise ${ }^{1}$, K.P. Paudyal ${ }^{2}$ and S.P. Srivastava ${ }^{3}$ \\ ${ }^{1}$ Agricultural Research Station, Dailekh, Nepal \\ ${ }^{2}$ Horticulture Research Division, NARC, Khumaltar, Lalitpur \\ ${ }^{3}$ Soil Science Division, Khumaltar, Lalitpur \\ e-mail: basantchalise@gmail.com
}

\begin{abstract}
A field experiment was conducted at National Citrus Research Program (NCRP), Paripatle, Dhankuta to determine the best grafting height for the highest success of grafting and the maximum growth of saplings during $1^{\text {st }}$ January to $30^{\text {th }}$ December, 2010. Scions were collected from the mother plant 'NCRP-49' grown under screen house and grafted onto one-year-old trifoliate orange seedling rootstocks by shoot-tip method at $4 \mathrm{~cm}, 8 \mathrm{~cm}, 12 \mathrm{~cm}, 16 \mathrm{~cm}$ and $20 \mathrm{~cm}$ height from the collar region as the treatment. The grafts were planted inside the closed tunnel made from bamboo splits, jute and plastic sheet at $10 \times 8 \mathrm{~cm}$ spacing in $64 \times 100 \mathrm{~cm}$ experimental plots laid out in randomized complete block design (RCBD) with four replications containing 80 grafts per plot. Treatments were allotted on the experimental plots randomly. The success of grafting was not affected by the height of grafting, however, growth of sapling was found significantly affected by the height of grafting. Observation taken on saplings after one year of grafting revealed that the maximum scion height $(42.13 \mathrm{~cm})$, the highest number of leaves per sapling $(47.50)$, the highest growth of scion diameter (55.61\%), maximum length of primary branches $(31.19 \mathrm{~cm})$, maximum number of secondary branches per sapling ((3.24), the highest length of secondary branches $(11.59 \mathrm{~cm})$, the highest canopy volume $\left(15440 \mathrm{~cm}^{3}\right)$ and the highest graft spread $(24.35 \mathrm{~cm})$ were found on the sapling grafted at $16 \mathrm{~cm}$ height of the trifoliate orange rootstock. Hence, from the study it is concluded that the most suitable height of grafting acid lime on trifoliate orange rootstock was $16 \mathrm{~cm}$.
\end{abstract}

Key words: Citrus aurantifolia, Poncirus trifoliata, shoot-tip, callus, graft success, graft spread and canopy volume

\section{Introduction}

Citrus is the most important fruit crop of mid-hill region of Nepal. APP (1995) has envisaged citrus as the number one priority crop for mid-hill region. Citrus is commercially cultivated in 42 mid-hill districts (Regmi et al. 2009). Acid lime (Citrus aurantifolia Swingle) is the second important citrus crop of Nepal after mandarin in terms of area coverage (MOAC 2012). Unlike mandarin and sweet orange, acid lime can be cultivated successfully from Terai to mid-hill region of Nepal. There is enormous scope of acid lime production in Nepal. About $95 \%$ of annual market demand of acid lime fruits supplied in the main season and $100 \%$ in the off-season in Kathmandu were imported from India (Dhakal et al. 2003). Dhakal et al. (2002) also reported that 2,110 tones of acid lime worth Rupees 60 millions is being imported annually from India. He also reported that $81 \%$ of acid lime saplings are raised from seedling in Nepal.

The production and productivity of acid lime is very low in Nepal due to the use of seedlings for plantation, less care and management of the orchard and plantation of saplings in marginal land. Moreover, the seedling trees are susceptible to Phytophthora root rot disease as compared to grafted ones. Saplings prepared by grafting acid lime onto trifoliate orange [Poncirus trifoliata (L.) Raf.] are tolerant of Phytophthora gummosis, cachexia-xyloporosis and nematodes, especially the Tylenchulus semipenetrans. The rootstock is also resistant to the citrus tristeza virus (Aubert \& Vullin, 1998). The demand of grafted 
sapling is growing day by day within the country. Trifoliate orange seedling has poor growth in open field condition. About two or more years old seedlings of trifoliate are being used for the grafting purpose. Some seedlings are very dwarf to be grafted with the suitable scions. Grafting at too low height can create the problem of rot disease at the point of union of the sapling after plantation. Therefore, a field experiment was carried out to find the suitable height of grafting at the National Citrus Research Program, Paripatle, Dhankuta giving the maximum success of grafting and the optimum growth of the saplings at nursery stage.

\section{Methodology}

The study was carried out at NCRP, Paripatle, Dhankuta, during $1^{\text {st }}$ January to $30^{\text {th }}$ December, 2010. About 8 months-old scions were taken from the mother plant of acid lime 'NCRP-49' accession grown inside the screen house. Scions were grafted onto one-yearold trifoliate orange seedling rootstocks by shoot-tip method at five different heights $(4 \mathrm{~cm}, 8 \mathrm{~cm}, 12 \mathrm{~cm}, 16$ $\mathrm{cm}$ and $20 \mathrm{~cm}$ ) from the collar region of the rootstock as the treatments. The grafts were planted inside the closed tunnel made from bamboo splits, jute sheet cover from inside and plastic sheet cover from outside at $10 \times 8 \mathrm{~cm}$ spacing in experimental plots laid out in randomized complete block design (RCBD) with four replications. Each $64 \times 100 \mathrm{~cm}$ sized experimental plots were supplied with a total of $10 \mathrm{~kg}$ vermi-compost (nitrogen 1.25-2.5\%, phosphorus $0.75-1.6 \%$ and potash $0.5-1.1 \%$ ) containing 80 grafts. The distances between replications and between plots were $50 \mathrm{~cm}$ and $25 \mathrm{~cm}$ respectively. Treatments were allotted on the experimental plots randomly. Ten plants were selected from each experimental plot for the study. The regular de-suckering, irrigation, crop protection, hoeing and top-dressing, removal of plastic laces, removal of jute and plastic sheet were done timely in each experimental plot for better growth of the saplings. The recorded data were reduced, arranged in MS-Excel and analyzed by MSTAT-C package. The means were separated by Duncan's Multiple Range Test (DMRT).

The amount of manure was slightly adjusted from the recommendation of Aubert and Vullin (1998), who recommended $80 \mathrm{mt} \mathrm{FYM,} 0.4 \mathrm{mt}$ TSP (Tripple Super Phosphate $\left(45 \% \mathrm{P}_{2} \mathrm{O}_{5}\right)$ and $0.5 \mathrm{mt}$ of Potassium Sulphate $\left(50 \% \mathrm{~K}_{2} \mathrm{O}\right)$ for open field production of citrus saplings. Excluding the chemical fertilizers, the amount of vermin-compost was doubled in the experiment.

\section{Results and Discussion}

\section{Graft success}

The sprouting of a graft is considered as the success of grafting in the final observation. At the initial observation, all the grafts were not sprouted, therefore success was not conformed. Graft success is the major criteria for the selection of a suitable method of grafting, time of grafting and grafting height of the saplings. In the present study, the success of grafting was not found to be significantly affected by the height of grafting. However, at final observation of success at 180 days after grafting, the highest success $(99.37 \%$ ) was given by $16 \mathrm{~cm}$ grafting height followed by $20 \mathrm{~cm}(99.06 \%)$ and the lowest (97.81\%) by $8 \mathrm{~cm}$. (Figure 1 ).

Present finding was also supported by Poon (1999) who reported $88.73 \%$, Gautam et al. (2001) reported $87.5 \%$, Chalise (2010) reported $77.78 \%$ success in mandarin with shoot-tip method whereas Adhikari (2006) reported $79.73 \%$ success in acid lime grafted onto trifoliate orange rootstock. The present result was higher than previous findings which may be due to more experienced grafters, more suitable temperature and humidity for callusing and more care of grafts after planting.

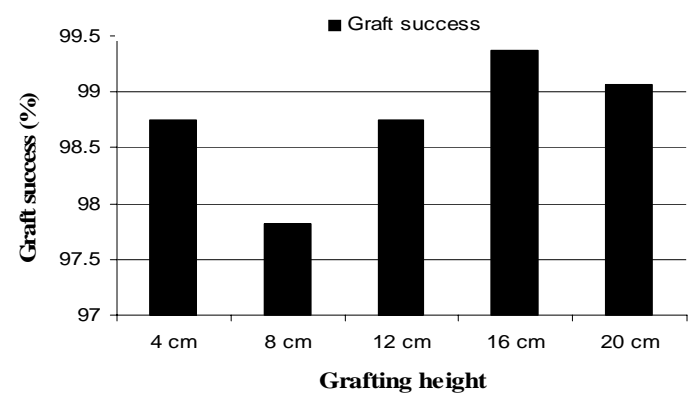

Fig. 1. Effect of grafting height on success of acid lime grafting at 180 days after grafting at Paripatle, Dhankuta, 2010

\section{Growth of scion height}

The growth of scion height was significantly affected by the grafting height at 180 and 300 days after grafting while non significant at rest of the observations. At 180 days after grafting, the maximum growth of scion height $(27.83 \mathrm{~cm})$ was given by $16 \mathrm{~cm}$ grafting height which was followed by grafting at $20 \mathrm{~cm}$ grafting height. Similarly, at 300 days after grafting, the highest growth of scion height $(39.75 \mathrm{~cm})$ was produced by sapling grafted at $16 \mathrm{~cm}$ height followed by $20 \mathrm{~cm}$ grafted saplings and the lowest by $4 \mathrm{~cm}$ grafted 
saplings. At 360 days after grafting the highest growth $(42.13 \mathrm{~cm})$ was again produced by $16 \mathrm{~cm}$ height grafted saplings and the lowest scion height by $4 \mathrm{~cm}$ height grafted saplings (Table 1).

Table 1. Effect of grafting height on growth of scion height of acid lime saplings at Paripatle, Dhankuta, 2010

\begin{tabular}{|c|c|c|c|c|c|c|}
\hline \multirow{2}{*}{$\begin{array}{c}\text { Treatments } \\
\text { (Grafting height) }\end{array}$} & \multicolumn{6}{|c|}{ Scion height $(\mathrm{cm})$} \\
\hline & $60 \mathrm{DAG}$ & $120 \mathrm{DAG}$ & $180 \mathrm{DAG}$ & $240 \mathrm{DAG}$ & $300 \mathrm{DAG}$ & $360 \mathrm{DAG}$ \\
\hline Grafting at $4 \mathrm{~cm}$ & 7.23 & 15.61 & $17.76^{\mathrm{c}}$ & 24.13 & $30.35^{\mathrm{b}}$ & 32.07 \\
\hline Grafting at $8 \mathrm{~cm}$ & 8.12 & 17.30 & $20.51^{\mathrm{bc}}$ & 25.66 & $30.39^{\mathrm{b}}$ & 33.64 \\
\hline Grafting at $12 \mathrm{~cm}$ & 8.60 & 18.44 & $22.94^{\mathrm{abc}}$ & 27.01 & $32.90^{\mathrm{ab}}$ & 35.09 \\
\hline Grafting at $16 \mathrm{~cm}$ & 7.40 & 19.18 & $27.83^{\mathrm{a}}$ & 31.24 & $39.75^{\mathrm{a}}$ & 42.13 \\
\hline Grafting at $20 \mathrm{~cm}$ & 6.94 & 17.56 & $23.69^{\mathrm{ab}}$ & 28.35 & $35.45^{\mathrm{ab}}$ & 38.11 \\
\hline F value & $0.86^{\mathrm{ns}}$ & $1.31^{\mathrm{ns}}$ & $5.08^{*}$ & $2.49^{\mathrm{ns}}$ & $3.35^{*}$ & $3.17^{\mathrm{ns}}$ \\
\hline CV $(\%)$ & 19.28 & 13.36 & 14.77 & 12.60 & 12.78 & 12.37 \\
\hline $\mathrm{CD}(\mathrm{P} \leq 0.05)$ & 2.27 & 3.63 & 5.13 & 5.29 & 6.65 & 6.90 \\
\hline $\mathrm{SEm} \pm$ & 0.74 & 1.18 & 1.67 & 1.72 & 2.16 & 2.24 \\
\hline
\end{tabular}

$\mathrm{SEm} \pm=$ Standard error of mean difference, $\mathrm{CV}=$ Coefficient of variation, $\mathrm{CD}=$ Critical difference at probability value 0.05 , Treatment means followed by common letter(s) are not significantly different at $5 \%$ by DMRT, DAG=Days after grafting

Present findings were also supported by Dubey and Singh (2003). They reported $29.53 \mathrm{~cm}$ scion height at 11 months after grafting Darjeeling mandarin grafted onto rough lemon rootstock. Scion height of $21.23 \mathrm{~cm}$ was reported by Adhikari (2006) in acid lime grafted onto trifoliate orange rootstock at 4 months after grafting. Similarly, Chalise (2010) reported $17.86 \mathrm{~cm}$ height of mandarin at 6 months after grafting onto trifoliate orange rootstock. However, the present result was higher than past findings.

\section{Number of leaves per sapling}

The number of leaves per sapling prepared by grafting at different height on the rootstock was found significant at 300 days after grafting while non significant at the rest of the observations. At 300 days after grafting, the significantly higher number of leaves per sapling (53.00) was given by the sapling grafted at $16 \mathrm{~cm}$ height which was followed by the sapling grafted at $12 \mathrm{~cm}$ height. Statistically, $12 \mathrm{~cm}$ and $16 \mathrm{~cm}$ grafting heights were at par. The lowest number of leaves was produced by the sapling grafted at the $4 \mathrm{~cm}$ height. At 360 days after grafting, all the grafting heights were not significantly different statistically, however, the maximum leaf number (47.50) was given by $16 \mathrm{~cm}$ height grafting (Table 2). This may be due to fast healing of the wounds of the grafts at this height.

Table 2. Effect of grafting height on number of leaves per sapling of acid lime at Paripatle, Dhankuta, 2010

\begin{tabular}{l|c|c|c|c|c|c}
\hline \multirow{2}{*}{$\begin{array}{c}\text { Treatments } \\
\text { (Grafting height) }\end{array}$} & \multicolumn{5}{|c}{ Number of leaves } \\
\cline { 2 - 7 } & 60 DAG & 120 DAG & 180 DAG & 240 DAG & 300 DAG & 360 DAG \\
\hline Grafting at $4 \mathrm{~cm}$ & 5.60 & 19.66 & 23.15 & 29.85 & $38.85^{\mathrm{b}}$ & 39.75 \\
Grafting at $8 \mathrm{~cm}$ & 7.00 & 21.50 & 23.13 & 32.22 & $43.05^{\mathrm{b}}$ & 42.58 \\
Grafting at $12 \mathrm{~cm}$ & 8.55 & 25.18 & 26.90 & 35.05 & $45.83^{\text {ab }}$ & 44.65 \\
Grafting at $16 \mathrm{~cm}$ & 7.45 & 24.53 & 25.80 & 31.95 & $53.00^{\mathrm{a}}$ & 47.50 \\
Grafting at $20 \mathrm{~cm}$ & 7.85 & 23.38 & 25.20 & 30.85 & $42.42^{\mathrm{b}}$ & 42.88 \\
F value & $2.59^{\text {ns }}$ & $2.19^{\text {ns }}$ & $1.22^{\text {ns }}$ & $0.92^{\text {ns }}$ & $3.47^{*}$ & $0.89^{\text {ns }}$ \\
CV (\%) & 18.77 & 13.39 & 12.13 & 12.70 & 12.74 & 13.89 \\
CD (P $\leq 0.05)$ & 2.11 & 4.71 & 4.64 & 6.26 & 8.76 & 9.30 \\
SEm \pm & 0.68 & 1.53 & 1.51 & 2.03 & 2.84 & 3.02 \\
\hline
\end{tabular}

$\mathrm{SEm} \pm=$ Standard error of mean difference, $\mathrm{CV}=$ Coefficient of variation, $\mathrm{CD}=\mathrm{Critical}$ difference at probability value 0.05 , Treatment means followed by common letter(s) are not significantly different at $5 \%$ by DMRT, DAG=Days after grafting

Present findings were also supported by Dubey and Singh (2003). They observed 47 leaves per sapling in Darjeeling mandarin grafted onto rough lemon at 330 days after grafting. In another study, Adhikari (2006) reported the highest number of leaves (47) per plant at 135 days after grafting in acid lime in Chitwan. Similarly, 
Chalise (2010) reported 48.47 leaves of mandarin sapling at 180 days after grafting.

\section{Growth of diameter}

The growth of diameter of different parts of saplings was studied during the research periods. The growth of collar diameter, below the union diameter and at the union diameter were found statistically non significant. However, the growth of scion diameter was found significant at 360 days after grafting. The highest growth (104\%) of collar region was given by $16 \mathrm{~cm}$ grafting height and the lowest $(69.11 \%)$ by $4 \mathrm{~cm}$ grafting height. Below the union diameter was maximum $(67.46 \%)$ in $8 \mathrm{~cm}$ grafting height and the lowest (54.14\%) in $20 \mathrm{~cm}$ height grafting. Similarly, the highest growth of union diameter (79.24\%) was given by $16 \mathrm{~cm}$ grafting height and the lowest $(62.34 \%)$ by $20 \mathrm{~cm}$ grafting height. The scion diameter growth was recorded maximum $(55.61 \%)$ in $16 \mathrm{~cm}$ grafting height and the minimum $(28.06 \%)$ in $8 \mathrm{~cm}$ grafting height. Among the four different parts of sapling the collar diameter growth was found maximum followed by union diameter and below the union diameter and the least growth on scion diameter (Figure 2).

\section{Number of primary branches per sapling}

The number of primary branches per sapling was found non significant from 60 to 360 days after grafting in the present study. However, at 360 days after grafting the highest number of primary branches
With discussing the growth of sapling diameter, Adhikari (2006) reported the highest growth (67.88\%) of the scion diameter, while Chalise (2010) recorded the highest growth $(60.33 \%)$ of collar diameter over the initial growth among collar diameter, below the union diameter union diameter and scion diameter.

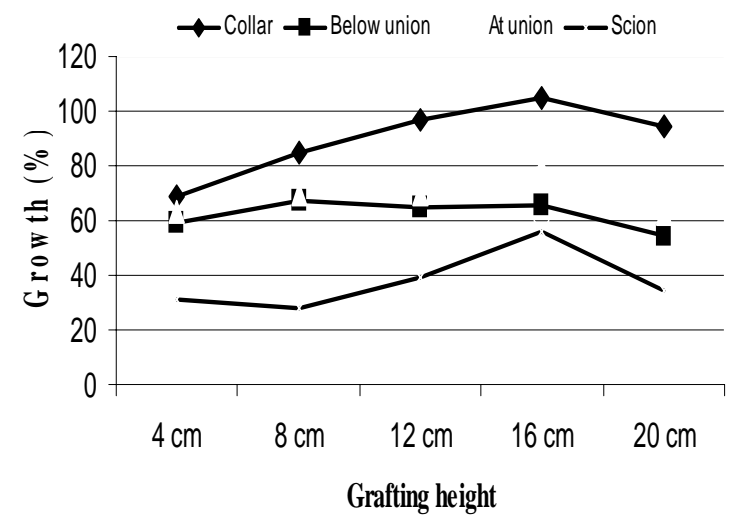

Fig. 2. Effect of grafting height on growth of diameter of different part of acid lime sapling over initial growth at 360 days after grafting in Paripatle, Dhankuta, 2010

per sapling (2.425) was produced by the sapling grafted at $12 \mathrm{~cm}$ height which was followed by $4 \mathrm{~cm}$ grafting height and the lowest number of primary branches was recorded in sapling grafted at $16 \mathrm{~cm}$ height (Table 3).

Table 3. Effect of grafting height on number of primary branches per sapling of acid lime at Paripatle, Dhankuta, 2010

\begin{tabular}{lcccccc}
\hline \multicolumn{1}{c}{ Treatments } & \multicolumn{5}{c}{ Number of primary branches } \\
(Grafting height) & 60 DAG & 120 DAG & 180 DAG & 240 DAG & 300 DAG & 360 DAG \\
\hline Grafting at $4 \mathrm{~cm}$ & 1.35 & 1.77 & 1.87 & 1.92 & 2.07 & 2.28 \\
Grafting at $8 \mathrm{~cm}$ & 1.42 & 1.72 & 1.75 & 1.77 & 1.86 & 2.12 \\
Grafting at $12 \mathrm{~cm}$ & 1.50 & 1.97 & 2.05 & 2.10 & 2.27 & 2.42 \\
Grafting at $16 \mathrm{~cm}$ & 1.55 & 1.65 & 1.65 & 1.74 & 1.84 & 2.09 \\
Grafting at $20 \mathrm{~cm}$ & 1.40 & 1.77 & 1.85 & 1.90 & 1.97 & 2.15 \\
F value & $0.78^{\text {ns }}$ & $0.65^{\text {ns }}$ & $0.97^{\text {ns }}$ & $0.93^{\text {ns }}$ & $2.04^{\text {ns }}$ & $0.68^{\text {ns }}$ \\
CV $(\%)$ & 12.54 & 16.76 & 16.38 & 15.68 & 12.39 & 15.04 \\
CD $(\mathrm{P} \leq 0.05)$ & 0.28 & 0.46 & 0.46 & 0.46 & 0.38 & 0.51 \\
SEm \pm & 0.09 & 0.15 & 0.15 & 0.15 & 0.12 & 0.17 \\
\hline
\end{tabular}

$\mathrm{SEm} \pm=$ Standard error of mean difference, $\mathrm{CV}=$ Coefficient of variation, $\mathrm{CD}=$ Critical difference at probability value 0.05 , Treatment means followed by common letter(s) are not significantly different at $5 \%$ by DMRT, DAG=Days after grafting

\section{Length of primary branches}

The length of primary branches was found significant at 180, 300 and 360 days after grafting while non significant at the rest of the observations. At 180 days after grafting the highest length of primary branches $(18.51 \mathrm{~cm})$ was recorded in $16 \mathrm{~cm}$ height grafted sapling 
B. Chalise et al./Effect of Grafting Height on Success.....

with which $12 \mathrm{~cm}$ and $20 \mathrm{~cm}$ were at par statistically and the lowest length $(11.70 \mathrm{~cm})$ was given $4 \mathrm{~cm}$ grafting height. At 300 days after grafting, maximum height $(27.92 \mathrm{~cm})$ was again given by $16 \mathrm{~cm}$ and the lowest $(20.55 \mathrm{~cm})$ by $4 \mathrm{~cm}$ height of grafting. At 360 days after grafting, the highest length $(31.19 \mathrm{~cm})$ was recorded in $16 \mathrm{~cm}$ height of grafting and the lowest $(21.86 \mathrm{~cm})$ in $4 \mathrm{~cm}$ grafting height (Table 4$)$.

Table 4. Effect of grafting height on length of primary branches of acid lime sapling at Paripatle, Dhankuta, 2010

\begin{tabular}{l|cccccc}
\hline \multirow{2}{*}{$\begin{array}{c}\text { Treatments } \\
\text { Grafting height })\end{array}$} & \multicolumn{5}{c}{ Length of primary branches $(\mathrm{cm})$} \\
\cline { 2 - 7 } & $60 \mathrm{DAG}$ & $120 \mathrm{DAG}$ & $180 \mathrm{DAG}$ & $240 \mathrm{DAG}$ & $300 \mathrm{DAG}$ & $360 \mathrm{DAG}$ \\
\hline Grafting at $4 \mathrm{~cm}$ & 4.54 & 10.20 & $11.70^{\mathrm{b}}$ & 16.54 & $20.55^{\mathrm{b}}$ & $21.86^{\mathrm{b}}$ \\
Grafting at $8 \mathrm{~cm}$ & 5.24 & 10.93 & $13.85^{\mathrm{b}}$ & 18.06 & $22.21^{\mathrm{b}}$ & $23.02^{\mathrm{b}}$ \\
Grafting at $12 \mathrm{~cm}$ & 5.77 & 11.49 & $14.65^{\mathrm{ab}}$ & 17.09 & $22.08^{\mathrm{b}}$ & $23.74^{\mathrm{b}}$ \\
Grafting at $16 \mathrm{~cm}$ & 4.97 & 12.37 & $18.51^{\mathrm{a}}$ & 22.83 & $27.92^{\mathrm{a}}$ & $31.19^{\mathrm{a}}$ \\
Grafting at $20 \mathrm{~cm}$ & 4.86 & 11.27 & $14.75^{\mathrm{ab}}$ & 19.07 & $25.20^{\mathrm{ab}}$ & $27.40^{\mathrm{a}}$ \\
F value & $0.66^{\mathrm{n}}$ & $0.81^{\text {ns }}$ & $3.39^{*}$ & $2.41^{\text {ns }}$ & $3.61^{*}$ & $4.28^{*}$ \\
$\mathrm{CV}(\%)$ & 22.32 & 15.70 & 18.19 & 17.13 & 13.16 & 14.54 \\
$\mathrm{CD}(\mathrm{P} \leq 0.05)$ & 1.75 & 2.72 & 4.12 & 4.94 & 4.78 & 5.70 \\
SEm \pm & 0.57 & 0.88 & 1.34 & 1.60 & 1.55 & 1.85 \\
\hline
\end{tabular}

$\mathrm{SEm} \pm=$ Standard error of mean difference, $\mathrm{CV}=$ Coefficient of variation, $\mathrm{CD}=$ Critical difference at probability value 0.05 , Treatment means followed by common letter(s) are not significantly different at $5 \%$ by DMRT, DAG=Days after grafting

\section{Number of secondary branches per sapling}

The secondary branches of sapling were recorded only after 4 months after grafting. The number of secondary branches were found non significant at 120 days to 360 days after grafting. However, at 360 days after grafting, the highest number of secondary branches (3.24) was produced by the sapling prepared by the grafting at $16 \mathrm{~cm}$ height which was followed by $12 \mathrm{~cm}$ height grafted sapling (3.158) and the lowest number (2.438) was produced by sapling grafted at $4 \mathrm{~cm}$ height (Table 5).

Table 5. Effect of grafting height on number of secondary branches per sapling of acid lime in Paripatle, Dhankuta, 2010

\begin{tabular}{l|ccccc}
\hline \multirow{2}{*}{$\begin{array}{c}\text { Treatments } \\
\text { (Grafting height) }\end{array}$} & \multicolumn{5}{c}{ Number of secondary branches } \\
\cline { 2 - 5 } Grafting at $4 \mathrm{~cm}$ & $120 \mathrm{DAG}$ & $180 \mathrm{DAG}$ & 240 DAG & 300 DAG & $360 \mathrm{DAG}$ \\
\hline Grafting at $8 \mathrm{~cm}$ & 0.62 & 1.15 & 1.49 & 2.12 & 2.44 \\
Grafting at $12 \mathrm{~cm}$ & 1.19 & 1.50 & 1.70 & 2.58 & 2.90 \\
Grafting at $16 \mathrm{~cm}$ & 1.30 & 1.86 & 2.03 & 2.71 & 3.16 \\
Grafting at $20 \mathrm{~cm}$ & 0.87 & 1.45 & 1.82 & 2.78 & 3.24 \\
F value & 1.32 & 1.54 & 1.66 & 2.26 & 2.74 \\
CV $(\%)$ & $1.21^{\mathrm{ns}}$ & $1.47^{\mathrm{ns}}$ & $0.62^{\mathrm{ns}}$ & $0.92^{\mathrm{ns}}$ & $1.07^{\mathrm{ns}}$ \\
$\mathrm{CD}(\mathrm{P} \leq 0.05)$ & 51.80 & 27.74 & 29.41 & 24.03 & 21.70 \\
SEm \pm & 0.85 & 0.64 & 0.79 & 0.92 & 0.97 \\
\hline
\end{tabular}

$\mathrm{SEm} \pm=$ Standard error of mean difference, $\mathrm{CV}=\mathrm{Coefficient}$ of variation, $\mathrm{CD}=\mathrm{Critical}$ difference at probability value 0.05 , Treatment means followed by common letter(s) are not significantly different at $5 \%$ by DMRT, DAG=Days after grafting

\section{Length of secondary branches}

The length of secondary branches was found significant at 180 and 360 days after grafting and non significant at the rest of observations. At 180 days after grafting, the highest length $(7.915 \mathrm{~cm})$ of secondary branches was recorded in $20 \mathrm{~cm}$ height grafted sapling which was followed by $12 \mathrm{~cm}$ grafted sapling $(7.445 \mathrm{~cm})$ and the lowest length $(5.425 \mathrm{~cm})$ by $4 \mathrm{~cm}$ height grafted sapling. At 360 days after grafting, the highest length $(11.59 \mathrm{~cm})$ of secondary branches was given by $16 \mathrm{~cm}$ height grafted sapling followed by $20 \mathrm{~cm}$ grafted sapling $(10.20 \mathrm{~cm})$ and the lowest $(9.215 \mathrm{~cm})$ by $8 \mathrm{~cm}$ height grafted sapling (Table 6). 
Nepal Journal of Science and Technology Vol. 14, No. 1 (2013) 25-32

Table 6. Effect of grafting height on length of secondary branches of acid lime sapling at Paripatle, Dhankuta, 2010

\begin{tabular}{|c|c|c|c|c|c|}
\hline Treatments & \multicolumn{5}{|c|}{ Length of secondary branches $(\mathrm{cm})$} \\
\hline (Grafting height) & $120 \mathrm{DAG}$ & $180 \mathrm{DAG}$ & $240 \mathrm{DAG}$ & $300 \mathrm{DAG}$ & $360 \mathrm{DAG}$ \\
\hline Grafting at $4 \mathrm{~cm}$ & 3.00 & $5.42^{\mathrm{b}}$ & 7.44 & 8.92 & $9.47^{\mathrm{b}}$ \\
\hline Grafting at $8 \mathrm{~cm}$ & 5.22 & $6.64^{\mathrm{ab}}$ & 7.73 & 8.64 & $9.21^{\mathrm{b}}$ \\
\hline Grafting at $12 \mathrm{~cm}$ & 5.50 & $7.44^{\mathrm{a}}$ & 8.30 & 9.49 & $9.79^{b}$ \\
\hline Grafting at $16 \mathrm{~cm}$ & 4.07 & $7.15^{\mathrm{a}}$ & 9.74 & 10.81 & $11.59^{\mathrm{a}}$ \\
\hline Grafting at $20 \mathrm{~cm}$ & 6.92 & $7.91^{\mathrm{a}}$ & 8.97 & 9.58 & $10.20^{\mathrm{ab}}$ \\
\hline F value & $1.79^{\mathrm{ns}}$ & $3.96^{*}$ & $3.24^{\mathrm{ns}}$ & $2.96^{\mathrm{ns}}$ & $3.65^{*}$ \\
\hline $\mathrm{CV}(\%)$ & 44.86 & 13.84 & 12.28 & 10.24 & 9.71 \\
\hline $\mathrm{CD}(\mathrm{P} \leq 0.05)$ & 3.41 & 1.47 & 1.60 & 1.50 & 1.50 \\
\hline $\mathrm{SEm} \pm$ & 1.11 & 0.48 & 0.52 & 0.48 & 0.49 \\
\hline
\end{tabular}

$\mathrm{SEm} \pm=$ Standard error of mean difference, $\mathrm{CV}=$ Coefficient of variation, $\mathrm{CD}=$ Critical difference at probability value 0.05 , Treatment means followed by common letter(s) are not significantly different at $5 \%$ by DMRT, DAG=Days after grafting

\section{Graft spread}

The average graft spread of sapling was found highly significant at 180, 300 and 360 days after grafting, significant at 240 days after grafting and non significant at the rest of the observations. At 180 days after grafting, the maximum graft spread $(12.43 \mathrm{~cm})$ was observed on $16 \mathrm{~cm}$ height grafted sapling and the minimum $(9.62 \mathrm{~cm})$ in $4 \mathrm{~cm}$ grafted sapling. Similarly, at 240 and 300 days after grafting the highest graft spread was given by sapling grafted at $16 \mathrm{~cm}$ height followed by $20 \mathrm{~cm}$ height grafted sapling and the lowest by $4 \mathrm{~cm}$ height grafted sapling. Again at 360 days after grafting, the extra graft spread $(24.35 \mathrm{~cm})$ was recorded in $16 \mathrm{~cm}$ height followed by $20 \mathrm{~cm}$ and the lowest in 4 $\mathrm{cm}$ height grafted sapling (Figure 3 ).

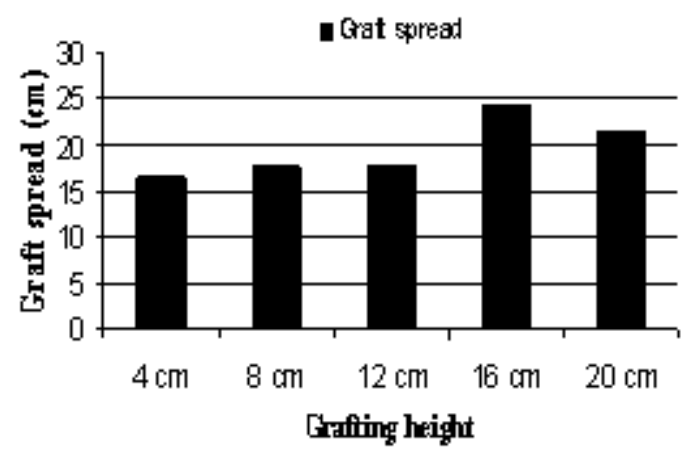

Fig. 3. Effect of grafting height on spread of acid lime sapling at 360 days after grafting at Paripatle, Dhankuta, 2010

\section{Canopy volume}

Canopy volume of sapling was calculated by the formula $\partial . D^{2} . H / 4$, where $\mathrm{D}=$ graft spread and $\mathrm{H}=$ Height of primary branch and expressed in $\mathrm{cm}^{3}$. A slight change in the graft spread and height can make much difference. The canopy volume of sapling was found significantly affected by the grafting height at 180 and 240 days after grafting and highly significantly affected at 300 and 360 days after grafting. From 180 to 360 days after grafting, the highest volume of canopy was recorded in sapling grafted at $16 \mathrm{~cm}$ height followed by $20 \mathrm{~cm}$ grafted ones and the lowest in $4 \mathrm{~cm}$ grafted sapling. At 360 days after grafting the highest canopy volume was recorded as $15440 \mathrm{~cm}^{3}$ followed by $9960 \mathrm{~cm}^{3}$ and the lowest $5101 \mathrm{~cm}^{3}$ (Figure 4).

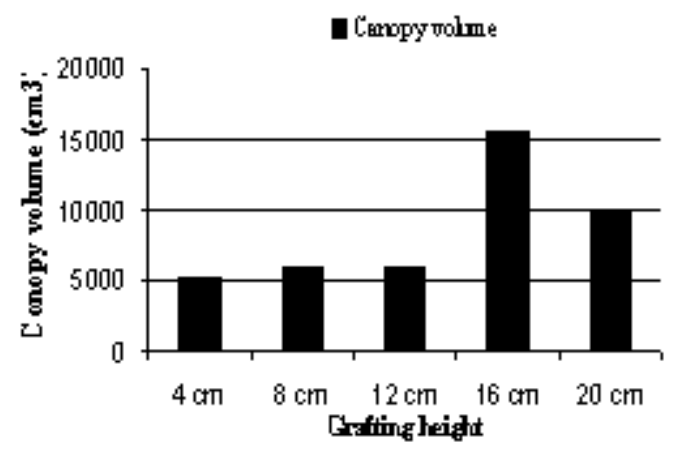

Fig. 4. Effect of grafting height on canopy volume of acid lime sapling at 360 days after grafting in Paripatle, Dhankuta, 2010

The recommended height of sapling in citrus species for plantation is $45 \mathrm{~cm}$ to $60 \mathrm{~cm}$ (Shah 1992). To attain this height, the age of the sapling should be one to one and half year for open field condition. Most of the citrus saplings are produced by grafting the desirable species/varieties onto the trifoliate orange rootstock. About one and half year is taken by the trifoliate orange to attain the graftable size which compels the nursery owners grafting at much lower height even at $2.5 \mathrm{~cm}$ or 


\section{B. Chalise et al./Effect of Grafting Height on Success.....}

less above the collar region. The lower grafting results the infection of the orchard tree at graft union by soilborne fulgal diseases when the union buried into the soil surface. The recommendation of the study is that grafting can successfully be done at any height started from $4 \mathrm{~cm}$ to $20 \mathrm{~cm}$ for success point of view only, however, the subsequent growth of sapling was found to be affected by the height of grafting. At shorter height, the growth of sapling was found slower and at higher grafting height the growth was found higher up to $16 \mathrm{~cm}$ only. Beyond this height sapling growth was again found retarded in the field condition. Thus from the study, the most appropriate grafting height of acid lime onto trifoliate orange was $16 \mathrm{~cm}$, since most of the growth parameters were found superior which meet the recommended quality parameters of the sapling within a year of grafting. Higher grafting also minimizes the possible attack of diseases at union in main field condition.

\section{Acknowledgements}

The authors would like to acknowledge all the technical staff of National Citrus Research Program (NCRP), Paripatle, Dhankuta for constant help during the trifoliate orange rootstocks production, grafting, intercultural operations and data recording.

\section{References}

Adhikari, A. 2006. Effect of grafting season on success and growth of acid lime (Citrus aurantifolia Swingle) in Rampur, Chitwan. M.Sc. Thesis. Tribhuvan University, IAAS, Rampur, Chitwan, Nepal. 99pp.

APP. 1995. Nepal agriculture perspective plan, (Final report). Agricultural Projects Services Center, Kathmandu, Nepal and John Mellor Associates, Inc., Washington DC, USA. 47p.

Aubert, B. and G. Vullin. 1998. Citrus nurseries and planting techniques. GTZ and CIRAD. Montellier Cedex 1, France. 183pp.
Chalise, B. 2010. Effect of grafting dates and methods on success and growth of mandarin (Citrus reticulata Blanco) Sapling. M.Sc. Thesis. Tribhuvan University, IAAS, Rampur, Chitwan, Nepal. 133pp.

Dhakal, D.D., S. Bhattarai, H.N. Bhandari and R.C. Bastakoti. 2003. Marketing system of lime and lemon in Nepal. Technical paper, Hill Agriculture Research Project, IAAS, Rampur, Chitwan, Nepal. $24 \mathrm{pp}$.

Dhakal, D.D., T.P. Gotame, S. Bhattarai and H.N. Bhandari. 2002. Assessment of lime and lemon production in Nepal. Journal of Institute of Agriculture and Animal Science 23:49-58.

Dubey, A.K. and A.K. Singh. 2003. Evaluation of rootstocks of different mandarins (Citrus reticulata) under foot-hills conditions of Arunachal Pradesh. Indian Journal of Agricultural Sciences 73(10):527529.

Gautam, I.P., D.N. Sah and B. Khatri. 2001. Effect of time of grafting and budding on trifoliate rootstocks for appropriate mandarin orange sapling production. Lumle Working Paper No. 2001/20. Lumle Agricultural Research Station, Lumle, Kaski, Nepal. $6 \mathrm{p}$.

MOAC. 2012. Statistical information on Nepalese agriculture 2008/2009. Ministry of Agriculture and Co-operatives, Agri-Business Promotion and Statistics Division. Singha Durbar, Kathmandu, Nepal. 170pp.

Poon, T.B. 1999. Effect of grafting methods and time on mandarin sapling production at Dailekh. In: Proceedings of the $2^{\text {nd }}$ National Horticultural Research Workshop, Khumaltar, Lalitpur, May 1315, 1998. pp. 65-68.

Regmi, C., I.P. Kafle, K.P. Paudyal, R.P. Devkota, G. Aryal and G. Awasthi. 2009. Screen house system to produce quality planting materials of Citrus in Banepa. In: Proceedings of the $5^{\text {th }}$ National Seminar on Horticulture, Kathmandu, Nepal, June 9-10, 2008. pp. 89-92.

Shah, R. B. 1992. Trainer's manual no. 16 citrus fruit. Manpower Development Agriculture Project, Kathmandu, Nepal. 523 p. 
Nepal Journal of Science and Technology Vol. 14, No. 2 (2013) 25-32 